\title{
Changes of Seed Germination during the Year
}

\author{
Ladislav Bláha, Jiří Hermuth \\ Crop Research Institute, Prague, Czech Republic \\ Email: opidum@volny.cz, hermuth@vurv.cz
}

Received 18 January 2016; accepted 27 March 2016; published 30 March 2016

Copyright (C) 2016 by authors and Scientific Research Publishing Inc.

This work is licensed under the Creative Commons Attribution International License (CC BY). http://creativecommons.org/licenses/by/4.0/

(c) (i) Open Access

\begin{abstract}
It is possible to conclude that typical course of graph which analyse course of germinability during the year at every cultivar is observable. Germination usually shows a minimum in December, but mainly in January and in February. Maximum of germinability is observed in the spring and summer time. This phenomenon isn't result of the dormancy or secondary dormancy because during of long term seed storage, germinability has similar curve every year, only number of germinative seeds stepwise decrease every year at every month of storage. Every species or cultivar of crops has a typical course of the germinability during the year. There are also species (crops), that have germination process during the year almost constant i.e., without variation during the year, but it is a minority of genotypes, rather exceptions. The annual course of germination is nearly identical to the annual course of the magnetic declination. From the theoretical practical view, there is possibility (but not certainty!) that in case of testing the seed germination at begin or end of year at genotypes with large variability of germinability during the year, that this phenomenon have negative impact on seed certification by companies producing seeds for cultivation practice in some species.
\end{abstract}

\section{Keywords}

Magnetic Declination, Magnetic Field, Influence of Magnetism, Seed Germination, Year Season

\section{Introduction}

Germination and vigor of seeds are two properties belonging to their essential characteristics. Their values are influenced by genotype, provenance and by lot of other factors. Surprisingly, these factors involve also effect of the Earth's magnetism. From this point of view, firstly, in the introduction, attention is given to a few comments 


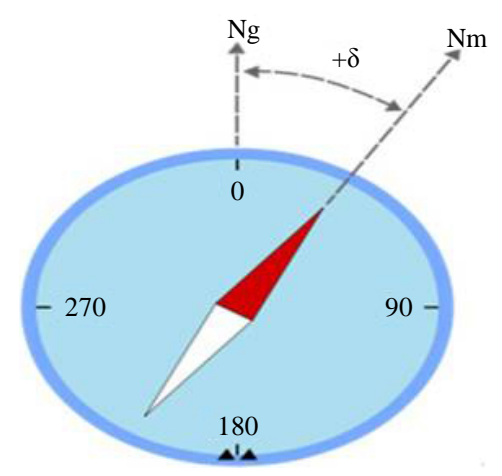

Figure 1. Example of magnetic declination showing a compass needle with a "positive" (or "easterly") variation from geographic north. $\mathrm{N}_{\mathrm{g}}$ is geographic or true north, $\mathrm{N}_{\mathrm{m}}$ is magnetic north, and $\delta$. (https://en.wikipedia.org/wiki/Magnetic declination).

concerning the Earth’s magnetic field and the magnetic declination

\section{1. magnetic Declination}

Magnetic declination is from the simple point of view (Figure 1) the angle on the horizontal plane between magnetic north and true north (the direction along a meridian towards the true geographic north Pole). This angle varies depending on position on the Earth's surface, and changes over time. In biology, Annual declination is very important in biology.

Declination is positive (by convention) when magnetic north is east of true north and negative when it is to the west. Isogonic lines are lines which the declination is zero, and are called agonic lines.

The Greek letter $\delta$ (delta) is very frequently used as the symbol for magnetic declination.

Magnetic declination has change over time and by influence of location. Magnetic declination varies both from place to place and with the passage of time. Lunar daily variation of the magnetic declination is important and has influence on the one year variation of the magnetic declination. Lunar daily variation creates during the 12 month annual course of declination.

Daily amplitude is shown in Figure 2. Annual course of changes of magnetic declination is in Figure 3 [1]. If the magnetic north deviates from the geographic to the right, declination reaches positive values; if the magnetic north deviates from the geographic to the left declination, value of declination is negative. If it matches, the declination is zero. As seen from the chart, the lowest value of declination during the year is in the begin of the year, an it is possible to say that in the current configuration of our solar system, the Earth finds closest to the Sun in January. The amplitude of daily variation in the summer is slightly smaller than that of the winter [2].

Additional information may be obtained at the following addresses which is viewed and supplemented with new information at begin of 2016 [3]-[8].

For the definition of the magnetic declination are obviously used the following indicators.

Declination: This term is used by those who analyze the magnetic field; this term is also used by land navigators. Also the similar term "magnetic declination" is used. This term is also preferred in biology.

From time to time, it is also possible to read other names: magnetic variation or magnetic deviation.

In case of variation (preferred by mariners, pilots and geomagneticians), it is term foranalyse changes in the magnetic field.

And only for information explanation of one indicator-deviation, it is definition of technical mistake which is results of influence of iron in a vehicle, aircraft etc.

\subsection{Importance of the Seed Traits}

The seed quality affects subsequent plant growth and development, plant physiology and in turn affects the quality of seeds.

The seeds were developed over a period of approximately 300 million years of phylogeny. The reason of the seeds development is to preserve the species, spread species and survive in unfavorable conditions (by the development of dormancy). 


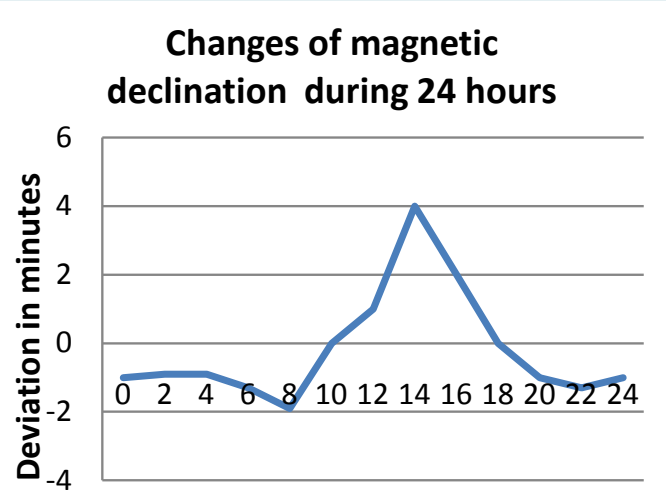

Figure 2. Daily amplitude (24 h) of magnetic declination variation in minutes.

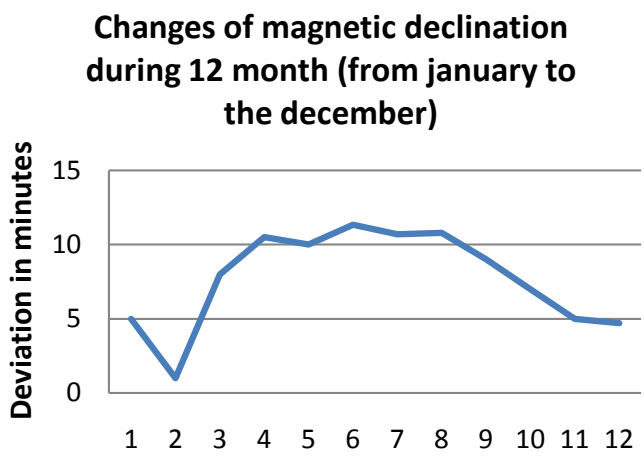

Figure 3. Annual amplitude of the magnetic declination-fluctuation is in minutes.

The quality of seeds (and alsoof the root system) is more and more desirable according toincreasingweather variability development and climate changes. Seed quality is in relation with the the plant integrity, i.e importance of root system for the seed growth and development is significant and these relationships exist also logically in opposite direction.

In case of analysis of importance of seeds for the production of plants, there are many scientific works which confirm importance of this trait. Seed quality is more and more important for plant production due to climatic changes [9]. Seed traits have influence on the seedling root growth and subsequent vegetative plant growth and development [10]. Seed sprouting can be modified by seed traits which are developed during seed growth [11].

It is need to provide selection for cultivar resistance to stress and on the quality of the plant root system already at the seed germination stage.Why? Quality of the embryonic roots is important for the following growth and development. This is a general biological regularity in nature because in the juvenile phase and in later stage, is active the same genotype! From this point of view it is possible to use testing the properties ofseedsandseedlingsfor resistance tophysicalstressorsfor theselection ofgenetic resources ofwinterrape and other crops [12].

Quality of the seeds is the cheapest agro-technical measures [13] [14]. Currently there are also a lot of important questions for future seed research. These topics can be briefly summarized as follows:

Problems of the farmers' seeds. Analysis of natural seeds traits. Utilisation of a wide range of regional and local varieties by species. Methods of the seed storage (=seed houses, genebanks). Varietal diversity as an important asset in the field of seeds? Evolution of the seed traits as an accompanying phenomenon in process of the plant breeding. Varietal diversity as an important asset in the research field of seeds. Importance of the utilisation of a wide range of regional and local varieties by species.

\subsection{What Was the Inspiration for this Work?}

Each plant species (cultivars) has typical optimal time of germination to optimise successful reproduction and survival. The reasons of this biological phenomenon are known, but during the year there is something like 
biological clock with the influence on the level of seed germination. This physiological phenomenon has large influence on rapidity of germination and on the germinability at a given time at some species and at some crops.

It is possible to conclude that typical common curve of rapidity of seed germination (similarly at seed vigour) within a year exists. The cultivars of some crops and wild plants have large differences within a year in a level of germination rapidity, i.e. there is problem of determination of acceptable time of seed testing for commercial purposes at sensitive genotypes.

\section{Material and Methods}

The eleven crops were tested in laboratory experiments in order to analysis of changes of rgermination rapidity (vigour) and germinability during the year-step by step in every month. The four repetitions in every test, i.e. every month were provided. One hundred of seeds of every species in every repetition was analysed. Germinability and vigour was analysed in Petri dishes with filter paper. Petri dishes were located in climatic chamber with the standard temperature $21^{\circ} \mathrm{C}$. Regularly humidification of filter paper with distilled water was provided.

In the experiments were used different crops selected on the basis of differences in development, origin from different centres of origin, length of vegetation period and chemical composition of the seeds.

In the case of foxtail millet, there was a choice of promising crop for central Europe due to gradual strengthening of drought [15].

Centre of origin is a geographical area where a group of organisms, either domesticated or wild, first developed its distinctive properties. Centers of origin are also considered as a sources of diversity.

Based on this viewpoint laboratory experiments from 2014 to the 2015 were provided with spring wheat (Triticum aestivum L) — cultivar Izzy, winter wheat (Triticum aestivum L-cultivar Bohemia, Sorghum (Sorghum bicolor var. eusorghum L) Moench) cultivar Ruzrok, oilseed radish (Raphanus sativus L. ssp. Oleiformes Pers)—cultivar Icarus, winter rape (Brassica napus, var. napus)—semi dwarf hybrid PX104, foxtail millet (Setaria italica L. Beauv)—cultivar Ruberit,safflower (Carthamus tinctorius L)—cultivar Sabina, rye tufted (Secale cereale var. multicaule, Bluebell)—cultivar Lesan, Buckwheat (Fagopyrum esculentum Moench.) cultivar Pyra, millet (Panicum miliaceum)—cultivar Hanácká, white mustard, (Sinapis alba L)—cultivar Severka and with the Purple phacelia (Phacelia tanacetifolia Benth) cultivar Větrovská.

\section{Results}

Figure 4. represents deviations of vitality (in \%) and germination of seeds (in \%) during the year, compared with a change of magnetic declination (in minutes = physical unit) during the year. The basis $100 \%$ for vitality and germination is always the lowest value during the year (in graph zero). That is to say, values on the $\mathrm{Y}$-axis are positive deviations from $100 \%$. The graph represents general course of relations i.e. the average across all the measured crops.

Obtained relations confirmed results from experiments of previous years. Significant (surprising) is almost complete conformity of these curves with the course of the magnetic declination during the every year.

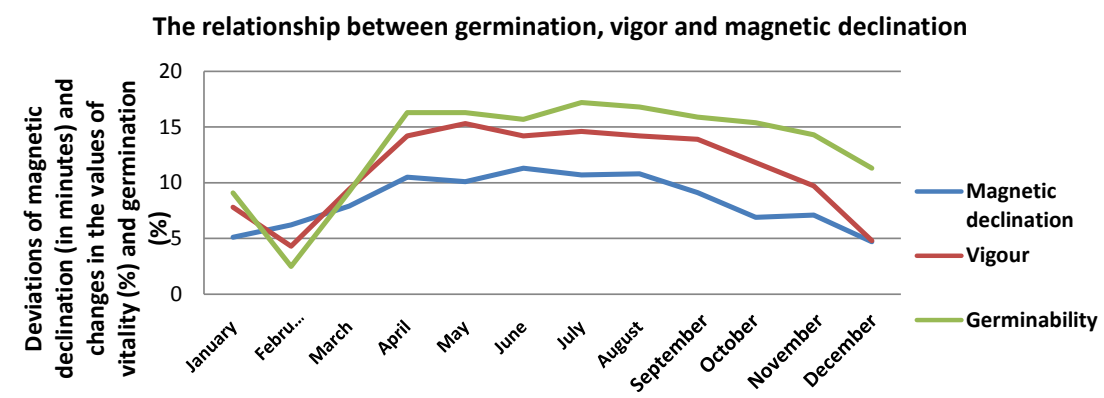

Figure 4. Deviations of vigour (in \%) and germination of seeds (in \%) during the year, compared with a change of magnetic declination (in minutes) during the year. The basis $100 \%$ for vitality and germination is always the lowest value during the year (in graph zero). The graph represents general course of relations i.e. the average across all the measured crops. 
In case of statistical analysis, the following correlations were obtained (across the all measured crops, repetitions and years).

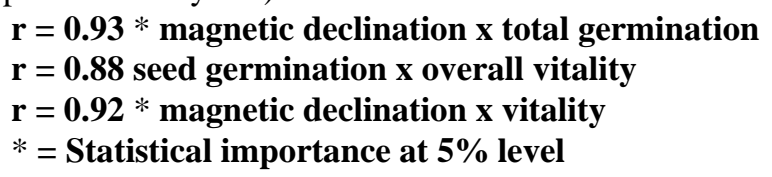

Figure 4 represents the general course, i.e. overall averageacross all crops with a minimum of vitality and germination of seeds in February. Individual crops are little different. Some crops have a minimum of vitality in December, at January safflower and at February (Figure 5).

Figure 6 represents time of sowing of analysed crops (gray color). Oilseed radish has spring, summer and outumn cultivars i.e., there is possibility for sowing of this crops during all vegetation period, Ryetufted has time of sowing across ale vegetation period and Purple phacelia has sowing time similar. At the other crops time of sowing, has approximately agreement with the highest values of germination (Figure 5).

Chart with the seeds vitality (Figure 7) is here to complement the data on germination, because it is a very important property. Maximum of vitality is usually lately, i.e. after sowing time (Figure 6) and after obtained maximum of germination (Figure 7).

It is interesting that there isn't decisive influence of temperature during germination, but as follows from the observations (not numerically substantiated) difference spring-summer is amplified in older seeds where germination is declining.

Verified been also, but only in a small number of samples that the seeds from the middle ear at cereals have less variability of germination during the year. It is also logic in view of the optimum ratio of storage compounds and plant hormones in the seeds.

Which are practical aspects arising from the obtained results?

Regardless of whether it is for the reader acceptable and unacceptable results showing "influence of magnetic declination on germination" during the year (or other physical indicators, which are results of declination changes), it would be good from a practical point of view take as a reality the fact of the existence of the phenomenon-differences in germination in some crops during the year.

Furthermore, as already stated, differences in the germination and vitality of seeds of less bred crops are during the year greater.

A similar effect can be even the course of results in some standard physiological experiments. Conclusions

\begin{tabular}{|c|c|c|c|c|c|c|c|c|c|c|c|c|c|}
\hline & & January & February & March & April & May & June & July & August & September & October & November & Decembe \\
\hline \multirow[t]{2}{*}{ Crop } & Cultivar & & & & & & & & & & & & \\
\hline & & & \multicolumn{11}{|c|}{ GERMINABILITY } \\
\hline $\begin{array}{c}\text { Foxtrail } \\
\text { millet }\end{array}$ & Ruberit & 4 & 4 & 5 & 5 & 4 & 3 & 4 & 4 & 3 & 3 & 2 & $\mathbf{0}$ \\
\hline Safflower & Sabina & $\mathbf{0}$ & 17 & 22 & 27 & 25 & 25 & 24 & 23 & 21 & 20 & 17 & 4 \\
\hline Rye tufted & Lesan & $\mathbf{0}$ & 4 & 10 & 21 & 20 & 18 & 19 & 18 & 17 & 13 & 9 & 6 \\
\hline $\begin{array}{c}\text { Purple } \\
\text { phacelia }\end{array}$ & Větrovská & 13 & $\mathbf{0}$ & 3 & 5 & 6 & 5 & 12 & 13 & 12 & 10 & 11 & 12 \\
\hline Buckwheat & Pyra & 23 & 0 & 11 & 17 & 17 & 15 & 16 & 17 & 18 & 19 & 19 & 22 \\
\hline Millet & $\begin{array}{c}\text { Hanácká } \\
\text { Mana }\end{array}$ & 15 & 0 & 13 & 21 & 21 & 18 & 19 & 18 & 15 & 13 & 13 & 15 \\
\hline $\begin{array}{c}\text { White } \\
\text { mustard }\end{array}$ & Severka & 6 & 0 & 11 & 24 & 25 & 23 & 21 & 20 & 20 & 19 & 17 & 12 \\
\hline $\begin{array}{l}\text { Winter } \\
\text { wheat }\end{array}$ & Bohemia & 7 & $\mathbf{0}$ & 4 & 8 & 7 & 7 & 8 & 7 & 8 & 8 & 8 & 7 \\
\hline Sorghum & Ruzrok & 4 & 0 & 7 & 23 & 24 & 25 & 28 & 26 & 24 & 24 & 22 & 13 \\
\hline $\begin{array}{l}\text { Oilseed } \\
\text { radish }\end{array}$ & Icarus & 15 & 0 & 8 & 16 & 18 & 21 & 24 & 23 & 22 & 22 & 22 & 16 \\
\hline $\begin{array}{l}\text { Winter } \\
\text { rape }\end{array}$ & PX104 & 18 & $\mathbf{0}$ & 14 & 27 & 28 & 28 & 29 & 30 & 29 & 31 & 30 & 26 \\
\hline $\begin{array}{l}\text { Spring } \\
\text { wheat }\end{array}$ & IZZY & 4 & 4 & 2 & & 1 & ( & & 1 & 2 & 3 & 2 & 3 \\
\hline
\end{tabular}

Figure 5. Deviations of germination of seeds (in \%) during the year at individual crops, the basis $100 \%$ for vitality and germination is always the lowest value during the year. Values on the Y-axis are values of deviations from $100 \%$. The figures in the table are average values rounded to whole numbers on for clarity. Zero is red; it is minimum in course of the year. Gray color represents the two highest values (more in the case of a tie highs in several cases). 
January February March April May June July August September October November December

$\begin{array}{cc}\text { Crop } & \text { Cultivar } \\ \text { Foxtail millet } & \text { Ruberit } \\ \text { Safflower } & \text { Sabina } \\ \text { Rye tufted } & \text { Lesan } \\ \text { Purple } & \text { Větrovská } \\ \text { phacelia } & \text { Pyra } \\ \text { Buckwheat } & \text { Hanácká } \\ \text { Millet } & \text { Mana } \\ \text { White } & \text { Severka } \\ \text { mustard } & \text { Bohemia } \\ \text { Winter wheat } & \text { Ruzrok } \\ \text { Sorghum } & \text { Icarus } \\ \text { Oilseed radish } & \text { PX104 } \\ \text { Winter rape } & \text { IZZY } \\ \text { Spring wheat } & \end{array}$

Time of sowing

Figure 6. Time of sowing of analysed crops.

\begin{tabular}{|c|c|c|c|c|c|c|c|c|c|c|c|c|c|}
\hline Crop & Cultivar & \multicolumn{12}{|c|}{ VIGOR } \\
\hline Spring wheat & IZZY & 4 & 5 & 4 & 3 & 2 & 2 & 1 & 1 & 0 & 0 & 1 & 1 \\
\hline Winter wheat & Bohemia & 7 & 11 & 21 & 22 & 26 & 23 & 19 & 20 & 21 & 21 & 19 & 0 \\
\hline Sorghum & Ruzrok & 3 & 6 & 16 & 19 & 19 & 23 & 28 & 27 & 25 & 25 & 17 & 0 \\
\hline Millet & $\begin{array}{l}\text { Hanácká } \\
\text { Mana }\end{array}$ & 2 & 4 & 16 & 18 & 19 & 16 & 10 & 5 & 4 & 2 & 1 & $\mathbf{0}$ \\
\hline $\begin{array}{l}\text { White } \\
\text { mustard }\end{array}$ & Severka & 2 & 4 & 7 & 8 & 10 & 7 & 1 & 1 & 1 & 1 & 1 & 0 \\
\hline Foxtai lillet & Ruberit & 9 & 6 & 7 & 10 & 13 & 10 & 11 & 11 & 10 & 10 & 10 & 0 \\
\hline Safflower & Sabina & 0 & 2 & 7 & 17 & 22 & 20 & 19 & 17 & 17 & 19 & 7 & 5 \\
\hline $\begin{array}{c}\text { Purple } \\
\text { phacelia }\end{array}$ & Větrovská & 0 & 1 & 3 & 5 & 5 & 5 & 5 & 5 & 5 & 4 & 4 & 2 \\
\hline Buckwheat & Pyra & $\mathbf{0}$ & 8 & 7 & 5 & 1 & 4 & 11 & 11 & 11 & 11 & 8 & 6 \\
\hline Oilseed radish & Icarus & 35 & 0 & 8 & 32 & 33 & 38 & 39 & 38 & 39 & 11 & 11 & 7 \\
\hline Winter rape & PX104 & 28 & 0 & 13 & 28 & 30 & 20 & 31 & 32 & 31 & 33 & 33 & 28 \\
\hline Rye tufted & Lesan & 3 & 5 & 4 & 3 & 3 & 2 & 0 & 2 & 3 & 4 & 4 & 3 \\
\hline
\end{tabular}

Figure 7. Deviations of vigour (in \%) during the year. The basis $100 \%$ for s always the lowest value during the year (in table it is zero). Values on the Y-axis are values of deviations from $100 \%$. The figures in the table are average values rounded to whole numbers on for clarity. Zero is red, it is minimum in course of the year. Gray color represents the two highest values (more in the case of a tie highs in several cases).

can then be different during the year at every repetition of the experiments. This assumption was confirmed by several staff (oral communication with colleagues in cytology, tissue culture, etc.).

\section{Discussion}

It should be noted that the obtained results, aren't problem of dormancy. Mentioned cycles were namely observed in past years often in additional control trials with the long term stored seeds of each species, crops, cultivars (=without dormance).

As indicated consultation with workers in other scientific disciplines (enzymology, tissue culture, cultivation 
of seedlings, gene manipulation etc.), they usually confirms mentioned trends-only from experience, unfortunately they numerically can't prove it.

Biological rhytmus is in plans is known [16]-[20].

Often this phenomenon is taken as for granted without further consideration of its cause, especially that in the period around january lot of specialised experiments do not have a high explanatory power due to reduced metabolic activity in this period. Different situation is at analysis of static magnetic field at laboratory experiments.

Effect of of static magnetic field-on the whole plants or on selected physiological processes is known for several years and there is about this phenomenon sufficient amount of literature [21]. But more attention is focused on the zoological research than on the plants).

Utilisation of the magnetic field could enhancement of germination of seeds. There is probability, that appliction of magnetic field influence is simple method for stimulation of germination, with caution, it is possible to say that $\mathrm{i}$ tis best methods to enhance a plant's growth and productivity [22].

Plant seeds under the influence of the magnetic field had a higher germination rate, and these plants grew taller, larger... so far has not been obtained a negative effect of magnetism on plants. However, the removal of the magnetic field weakened the plant stem, suggesting the role of magnetism in supplying plants with energy. More detailed information relating to the metabolism of plants and seeds are shown clearly in the literary review [23].

Obtained results supports the hypothesis that GMF (geomagnetic field) reversal contributes to inducing changes in plant development that might justify a higher selective pressure, eventually leading to plant evolution. The possible role of GMF on plant evolution and the nature of the magnetoreceptor is also discussed [24].

At the observed phenomenon in presented work we can speak with certainty that analysed dependency exists. There are also repeated found of evidence of positive and previously significant correlations, but direct evidence is lacking, i.e. evidence that the relationship between the parameters of the magnetism and metabolic functions of germinating seeds weren't't found, similarly also in the literature and at www pages, it can be also a mistake of authors.

Similar results were obtained a few years ago (from 2005 to 2007) at experiments with rape, wheat and with less common field crops. In the previous years other crops were analyzed by the same procedure [25] [26]. Last results with identical conclusions were published in early 2016 [27].

In next text firstly is presented group of results from previous years (first group) and for control, was provided analysis of the multipurpose experiments with the rapeseed and with the cereals-it is "second" following presented group (extrapolated results).

The first named group of results was obtained from similar experiments from the years 2006-2007. These results confirm the obtained above named conclusions from the last experiments. This laboratory experiences were realized since October 2006 to September 2007. For experiments were used 8 selected crops: spring Wheat (Triticum aestivum L), winter Wheat (Triticum aestivum L), Fodder mallow (Malva verticillata L), White sweet clover (Meliotus albus Medic), Canary grass (Phalaris canariensis L), Rye (Secale cereale L. var. multicaule) and Phacelia (Phacelia tanacetifolia Benth) The laboratory experiences with selected crops were provided simultaneously in research institutes in Praha-Ruzyně and in Research Instiutute for Fodder Crops Troubsko. Experiments were performed in three weeks long repeated cycle during the whole year. It follows from the obtained results, that minimum rapidity of germination in autumn exists (November, December, January) and maximum is in before spring. Every crop has specific course of germinability. Basic information about the total germinability of all analysed crops during the year is possible to see.

In Figure 8, correlation coefficients confirm also so far obtained results In case of analysis of individual crops the germination of winter wheat, spring wheat, canary grass and rye oscillated minimally, but at other crops especially at the germination of fodder mallow, white sweet and white sweet clover has more fluctuating curve during individual measuring. It is difficult to identify causes of different sensitivity of crop cultivars.

\section{$\mathbf{r}=\mathbf{0 . 7 9}$ magnetic declination $\mathrm{x}$ total germination \\ $r=0.78$ seed germination $x$ overall vitality \\ $r=0.72$ magnetic declination $x$ vitality}

But what is interesting? The obtained values of the correlation coefficient at this group of crops are slightly lower, but results are very similar.

The second group where was used extrapolation of results for control from different experiments of the 


\section{Germination}

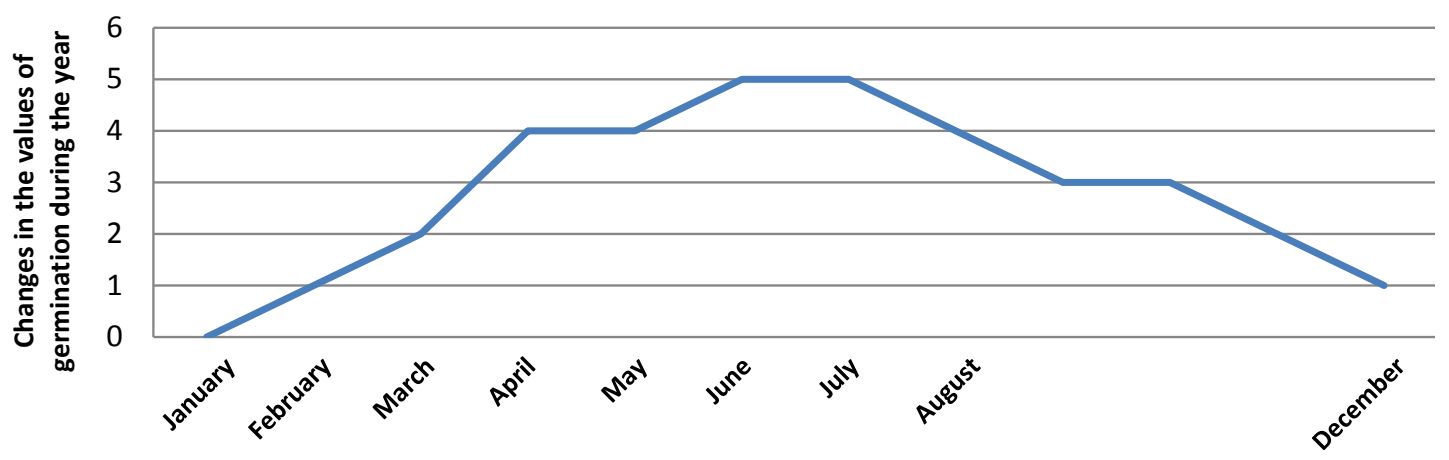

Figure 8. Deviations of germination of seeds (in \%) during the year. The basis $100 \%$ for germination is the lowest value during the year. The graph represents general course of relations i.e. the average across all the measured crops, repetitions and experimental years (Vitality has a similar course, but the data for the past years have few data, therefore not listed).

projects with rapeseed and cereals where germination and vigour of seeds were analysed across the every experimental year.

The experiments were provided during last five years (Project of Ministry of Agriculture Czech Republic, i.e. projects related to the rapeseed and of the problems of farmers' seeds).

For objectivity it should be noted, that although there are multiannual experiments, with a lot of varieties and with a large number of repeating experiments and that the experiments give sufficient results, but the number of measurements at different times of the year is different (sufficient, but not constant). Method of the seed testing is also standard (identical) as at all presented experiments. Basic information are in Figure 9, Figure 10.

At time of seed testing may be problems such as secondary dormancy, less well-known influence of the year season, magnetic field variation etc.

As already noted, in this work presented results aren't under influence of dormancy, because they are repeatable every year with the utilisation of sequentially stepwise aging seeds of the same crops and varieties. For more information about physiology of sprouting lot of scientific papers,textbooks and books exists. For example [28]-[30].

For interest here is submitted an example where dormancy is a very important element in assessing seeds, i.e. opposite example.

However dormancy may be important role in seeding mixtures for a the reconstruction ecologically important sites.Germinability must be immediately known after harvest seed germination in order to optimize the species ratio of the mixture intended for sowing. As a one example is following solution presented by [31]-[33].

The basic aim connected with the wild plants' seed collecting is the evaluation of their germination in order to return this species to the nature, i.e. for species-rich meadows' restoration in Bile Karpaty Mountains.

Standard testing methods used by agricultural laboratories are not suitable on account to very long time of gradual sprouting (influence of dormancy at wild species) and contamination by fungi, which disable to obtain the acurate results. For this purpose an effort for developing of special quick orientation test was made. In experiments with the wild plants one of the goals was to find a fast method for wild plants' germinability testing, which would give-after one week testing (after destruction of dormancy) - the same similar or better results as testing by standard metods after several weeks.

Germinability was analysed in Petri dishes with filter paper or in cultivation pots $40 \times 60 \times 10 \mathrm{~cm}$ with the soil or with the squartz sand. Gradually was tested 9 procedures based on the physiology of dormancy, enabling the elimination of dormancy, for establishement of species germinability allowing the establishment of assortment of seeds for sowing (species ratio)/jen jednotlivé nadpisy/cold stress $=-1^{\circ} \mathrm{C}$ for 48 hours, high temperature stress $=32^{\circ} \mathrm{C}$ for 48 hours, combination of stresses $=40^{\circ} \mathrm{C}$ for 24 hours, $0^{\circ} \mathrm{C}$ for 24 hours, soil $=$ sowing to the soil, surface was slightly covered by fine sand, sand = sowing to the sand, surfrace was slightly covered by fine sand, soaking = soaking before sowing-three variants: 6 h (Soaking 1), 24 h (Soaking 2) a 48 hod (Soaking 3). After soaking seed was sown to the sand, vernalization $=0^{\circ} \mathrm{C}$ for one month, humidity $90 \%-100 \%$, dark; alternating temperature $=$ soaking for two days (destilled water, filter paper), after that alternating 


\section{Winter wheat}

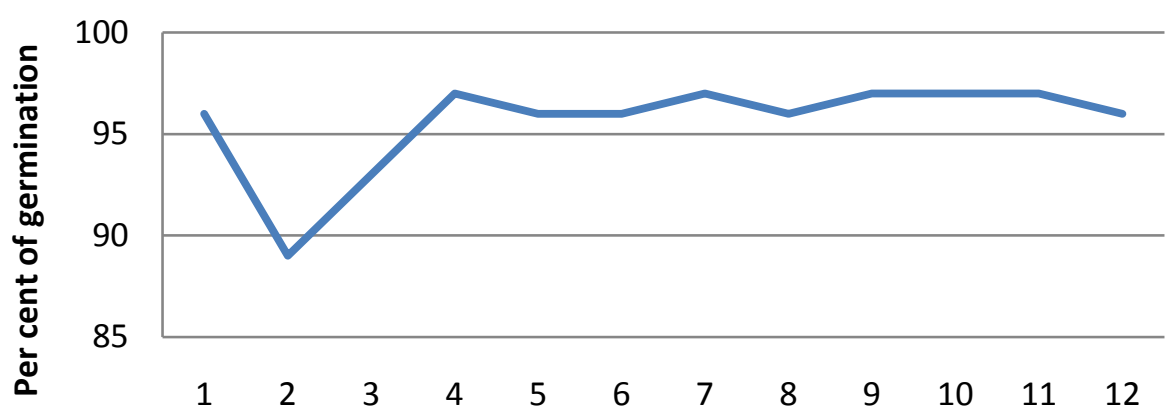

Figure 9. Per cent of germination of seeds (in \%), across of all cultivars. Average of 3 years and localities.

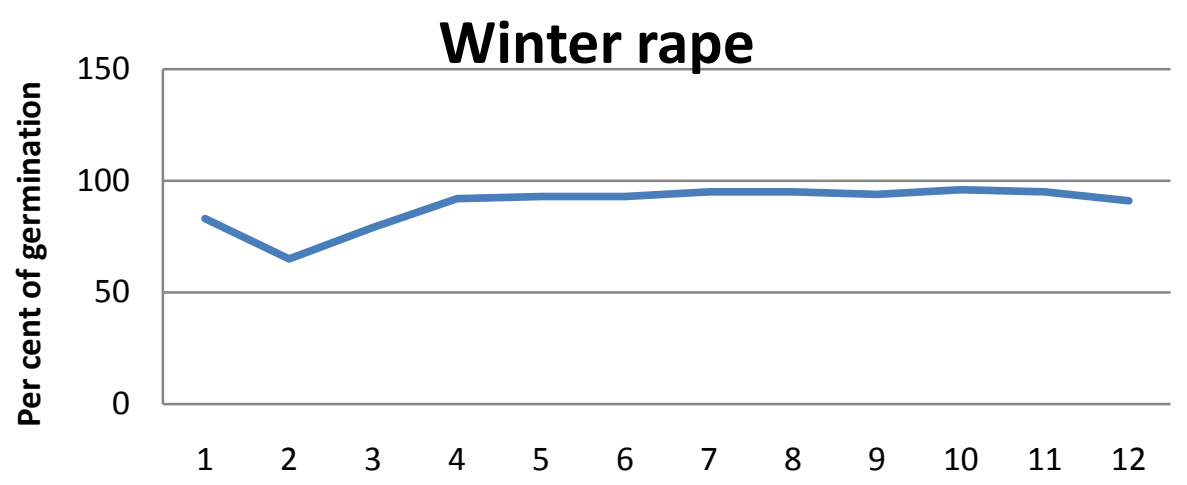

Figure 10. Per cent of germination of seeds (in \%), across of all cultivars. Average of 3 years and localities.

of $30^{\circ} \mathrm{C}$ for 12 hours and $5^{\circ} \mathrm{C}$ for 12 hours and finally sowing to the soil. As control variant standard laboratory method for germination testing was applied (Petri dishes and filter paper) for one month, $25^{\circ} \mathrm{C}$, light regime $12 \mathrm{~h}$ day and 12 night.

As follows from obtained results (Figure 1), the best methods are (1) two days soaking in distilled water or (2) combination of stresses (alternating 12 hours of $30^{\circ} \mathrm{C}$ and 12 hours of $5^{\circ} \mathrm{C}$ ) followed by sowing to the damp sand with regular humidification of sand surface by destilled water.

\section{Conclusions}

We can conclude that each crop has typical sowing time to optimise successful reproduction, survival and yield (= agro-technical term). At the sowing time, it is important to know percent of germinability, vigour of seeds etc. But during the year, there something like biological clock exists. This physiological phenomenon has large influence on rapidity of germination and on the germinability.

As was already mentioned, significant and surprising is almost complete conformity of the curves of seed germinability (seed vigour) with the course of the magnetic declination during the every year. It is possible to conclude that typical standard curves of rapidity of seed germination during a year at different crops exist. The cultivars of some crops and wild plants have differences within a year in a level of germination and at germination rapidity, i.e. there can be problem of determination of acceptable time of the year for seed testing for commercial purposes at some crops. From the theoretical view, crops and their varieties that have lower winter level of germination can be in case of their testing for commercial purposes underestimated.

The magnetic field has an effect on the metabolism of plants, animals and humans. It is interesting to know whether the current slow-motion of magnetic poles has an influence (along with the impact of climate change) on seed traits and consequently on the representation of plant species, such as in Central Europe. That is to say, influence on the development and composition of ecosytems. 


\section{Ackownledgements}

This work was supported by Projects No. RO0415, The Ministry of Agriculture of the Czech Republic.

\section{References}

[1] Hánek, P. and Novák, Z. (2008) Důlní měřictví. Geodezie v podzemních prostorách 10, Skriptum Českého Vysokého Učení Technického v Praze (Mine Surveying. Geodesy in Underground Areas 10, Textbooks of Czech Technical University in Prague), 4-28.

[2] Onwumechilli (1960) Lunar Daily Variation of the Magnetic Declination at Ibadan, Nigeria. Journal of Geophysical Research, 65, 3433-3435. http://dx.doi.org/10.1029/JZ065i010p03433

[3] Magnetic Declination. http://www.geomag.nrcan.gc.ca/mag_fld/magdec-en.php

[4] Ressources Naturelles Canada. http://www.geomag.nrcan.gc.ca/mag fld/magdec-fr.php

[5] Magnetic Declination. From Wikipedia, the Free Encyclopedia. https://en.wikipedia.org/wiki/Magnetic_declination\#cite_ref-2

[6] Magnetic Declination. From Wikipedia, the Free Encyclopedia. https://en.wikipedia.org/wiki/Magnetic_declination

[7] L'influence du magnétisme sur les plantes. https://www.google.cz/search?sourceid=navclient\&hl=cs\&ie=UTF-8\&rlz=1T4ADFA_csCZ465CZ466\&q=L\%e2\%80 \%99influence+du+magn\%c3\%a9tisme+sur++les+plantes

[8] Déclinaison magnétique, ressources naturelles, Canada. http://www.geomag.nrcan.gc.ca/mag_fld/magdec-fr.php

[9] Adams, F. (2012) Le futur des semences et les semences du futur .Veröffentlicht am 28, Oktober 2012.

[10] Bláha, L. and Pazderů, K. (2013) Influence of the Root and Seed Traits on Tolerance to Abiotic Stress. In: Stoytcheva, M. and Zlatev, R., Eds., Agricultiural Chemistry, INTECH, Croatia, 89-113.

http://www.intechopen.com/books/agricultural-chemistry/influence-of-the-root-and-seed-traits-on-tolerance-to-abiotic$\underline{\text { stress }}$

[11] Št’astný, J. and Pazderů, K. (2008) Evaluation of Winter Wheat (Triticum aestivum L.) Seed Quality and Seed Quality Stability in Relation to Varieties and Environmental Conditions. Journal of Agrobiology, 25, 153-161.

[12] Bláha, L. And Vyvadilová, M. (2013) Metodika testování vlastností semen a klíčních rostlin na odolnost vůči fyzikálním stresorům pro selekci genetických zdrojů řepky zimé (Methodology Fortesting the Properties of Seeds and Seedlings for Resistance Tophysical Stressors for the Selection of Genetic Resources of Winterrape). Methodology of Crop Research Institute, Prague, 15. (In Czech)

[13] Bláha, L. (2015) Seed and Seedling Traits for the Rapeseed Yield Improvement. Vol. 53, Lambert Academic Publishing.

[14] Bláha, L. (2015) Significance of Seed and Root Crop Properties in Organic Farming. In: Gorawala, P. and Mandhatri, S., Eds., Agricultural Research Updates, 9, 25-41.

[15] Hermuth, J., Janovská, D. and Prohasková, A. (2015) Bér Vlašský, Setaria italica (L.) Beauv., plodina vhodná do měnícího se klimatu České republiky. Metodika pro praxi (Foxtail millet, Setaria italica (L.) Beauv. A Crop Suitable to the Changing Climate of the Czech Republic. Methodology for Practice.Výzkumný ústav rostliné výroby, v.v.i., Crop Research Institute, Praha-Ruzyně. http://www.vurv.cz/sites/File/Publications/ISBN978-80-7427-175-5.pdf

[16] Mancuso, S. and Shabala, S. (2007) Rhytms in Plants. Springer-Verlag, 264.

[17] Mc Clung, C.R. (2006) Plant Circadian Rhytms. The Plant Cell, 18, 792-803.

http://www.plantcell.org/content/18/4/792.short http://dx.doi.org/10.1105/tpc.106.040980

[18] Kummerow, J. (1965) Endogenous Rhytmic Oscillations in the Germination of Seeds (in German). Ecyclopedia of Plant Physiology, 15, 721-726.

[19] Thain, S.C., Hall., A., et al. (2000) Functional Independence of Circadian Clocks That Regulates Plant Gene Expression. Current Biology, 10, 951-956. http://dx.doi.org/10.1016/S0960-9822(00)00630-8

[20] Webb, A.A.R. (2003) The Physiology of Circadian Rhythms in Plants. New phytologist s, 160, 281-283.

[21] Maffei, E.M. (2014) Magnetic Field Effects on Plant Growth, Development, and Evolution. Frontiers in Plant Science, 5, 445. http://dx.doi.org/10.3389/fpls.2014.00445

[22] Hoazyn, M., El-Mahdy, A.A.A. and Abdel-Rahan, H.M.H. (2015) Effect of Magnetic Field on Germination, Seedling Growth and Cytogenetic of Onion (Allium cepa L.). African Journal of Agricultural Research, 10, 849-857.

http://www.academicjournals.org/journal/AJAR/article-full-text-pdf/7CE049D50674

http://dx.doi.org/10.5897/ajar2014.9383 
[23] Fu, E. (2012) The Effects of Magnetic Fields on Plant Growth and Health. Young Scientists Journal, 5, 38. http://dx.doi.org/10.4103/0974-6102.97696

[24] Bertea, C., Narayana, R., Agliassa, C., Rodgers, C.T. and Maffei, M.E.J. (2015) Geomagnetic Field (Gmf) and Plant Evolution: Investigating the Effects of Gmf Reversal on Arabidopsis thaliana Development and Gene Expression. Journal of Visualized Experiments, No. 105, e53286. http://dx.doi.org/10.3791/53286

[25] Bláha, L. and Gottwaldová, P. (2008) Changes of Seed Germination during the Year. Italian Journal of Agronomy, 3, 387-388. www.agronomy.it/index.php/agro/issue/archive

[26] Bláha, L. and Gottwaldová, P. (2007) Změny klíčivosti semen v průběhu roku [Changes of Germination during the Year]. Úroda, No. 12, 64-65.

[27] Bláha, L. and Hermuth, J. (2016) Co ukazují výsledky měření klíčivosti a vitality semen vybraných plodin v průběhu kalendářního roku [What Is Result of Measurement of Germination and Vitality of Seeds of Crops during the Calendar Year). Agromanuál, 11, 58-61. (In Czech) www.agromanual.cz/cz/casopis-agromanual/agromanual-2016-1.html

[28] Deno, N.C. (1993) Seed Germination Theory and Practice. Second Edition, Norman C. Deno, State College, 242 p.

[29] Deno, N.C. (1996) First Supplement to Seed Germination Theory and Practice. Norman C. Deno, State College, 107.

[30] Deno, N.C. (1998) Second Supplement to Seed Germination Theory and Practice. Norman C. Deno, State College, 101.

[31] Poková, H. and Bláha, L. (2008) Testování klíčivosti semen planých druhů [Testing Germination of Wild Species]. Úroda, 61, 63-66.

[32] Bláha, L. and Poková, H. (2008) Evaluation of Germination of Wild Plants in Order to Return This Species to the Nature. Italian Journal of Agronomy, 3, 369-370. www.agronomy.it/index.php/agro/issue/archive

[33] Bláha, L. and Poková, H. (2009) Test umožňujicí paralelni rychlé hodnoceni kličivosti druhů s odlišným stupněm dormance [Test Enabling Parallel Rapid Assessment Germination of Species with Different Degrees of Dormancy]. Osivo a sadba. IX. Specialized Scientific Seminar, 153-157. https://home.czu.cz/pazderu/publikace/ 